\title{
Die gesigpunt van die verteller en die funksie van die Jerusalemgemeente binne die "opsommings" in Handelinge
}

\author{
S J JOUBERT
}

\begin{abstract}
The point of view of the narrator and the function of the Jerusalem congregation within the summaries in Acts

This paper focusses on Luke's presentation of the Jerusalem congregation in the summaries (Acts 2:42-47, 4:32-35, and 5:12-16) and their function within the narrative framework of Acts. A brief investigation of the author-narrator's point of view makes it clear that it is not his aim to give a comprehensive account or a biography of the Jerusalem congregation. The references to them in the summaries are solely employed to support the overarching theme of Acts. As secondary characters within the broader narrative framework of Acts they therefore serve as the visible fulfilment of the first part of Christ's promise to the apostles in chapter 1:8.
\end{abstract}

Alhoewel die "opsommings" (beter bekend as die "Summaries" of "Sammelberichte"), te wete Handelinge $2: 42-47 ; 4: 32-35$ en 5:12-16, deur baie navorsers as ' $n$ belangrike bron van inligting aangaande omstandighede in die beginstadium van die Jerusalemgemeente beskou word, bly die historiese betroubaarheid van hierdie gedeeltes in die besonder en Handelinge in die algemeen tot op hede 'n geweldige dispuutpunt binne die Nuwe-Testamentiese wetenskap. F C Baur en die Tübinger Schule het veral die leiding in dié verband geneem deur Handelinge as 'n tweedeeeuse tendensieuse geskrif te bestempel wat dit ten doel gehad het om die botsende Joodse en heidense groepe binne die kerk te probeer versoen. Daarom is Lukas se voorstelling van die vroeë kerk "...ein sehr schwaches und unklares Bild, das für die geschichtliche Betrachtung wenig sicheres darbietet"." Genoemde tipe standpunt is uiteraard van velerlei kante bestry onder andere deur persone soos W M Ramsay, Adolf von Harnack en andere wat op hulle beurt weer ingestaan het vir die historiese geloofwaardigheid van Handelinge. ${ }^{2)}$

Soos reeds gesê, konsentreer die huidige navorsing ten opsigte van die "opsommings" steeds in 'n groot mate op basiese vrae soos die betroubaarheid en oorsprong van die stof wat hierin aangetref word. ${ }^{3)}$ Hierdie artikel wil nie tot dié debat toetree of antwoorde op bogenoemde vrae probeer verstrek nie. Veel eerder wil dit die opsommings vanuit 'n literêre hoek benader en die algemene riglyne wat die verteller self vir die verstaan 
daarvan neerlê, aan die lig probeer bring. In die verlede is betroubaarheid eenvoudig te veel met historiese betroubaarheid in verband gebring en te min met 'n outeur/verteller se getrouheid aan die implisiete norme van sy werk self. ${ }^{4)}$ So 'n benadering kan maklik aanleiding gee tot die stel van verkeerde vrae, en met name verkeerde historiese vrae aan tekste. $\mathrm{Na}$ tuurlik impliseer pasgenoemde opmerking geensins dat daar telkens net een korrekte lesing van die afsonderlike tekste sou bestaan nie. Daar heers immers vir 'n geruime tyd in 'n groot mate konsensus onder navorsers dat tekste meerdere betekenisse kan hê. ${ }^{5 \prime}$ Die lees van tekste is immers 'n aktiewe proses van betekenisverlening en bestaan daarom “...nie slegs uit die dekodering van kodes wat in 'n tekensisteem geënkodeer is nie". 6) Tog beteken dit aan die ander kant egter ook nie dat tekste willoos aan enige interpretasie van die verskillende lesers daarvan uitgelewer is soos wat onder andere Stanley Fish' beweer nie. Tekste bied immers self ' $n$ objektiewe basis vir die evaluasie daarvan en verskaf ook die riglyne "...vir die wyse waarop dit gelees (geïnterpreteer) wil wees en ook vir verbandlegging na buite die teks".8) Hierdie riglyne en norme wat deur die teks self daargestel word, legitimeer sekere lesings, en andere nie.

\section{Handelinge as 'n narratiewe teks}

Handelinge ressorteer saam met die Evangelies en Openbaring onder die verteltekste van die Nuwe Testament, aangesien dit volgens Scholes en Kellogg se definisie aan die basiese vereistes van die narratiewe genre voldoen, te wete die aanwesigheid van 'n verteller en 'n verhaal. ${ }^{9)}$ ' $n$ Narratief sou egter ook nader omskryf kon word as die saamgroepering van 'n aantal gegewens in 'n geordende en gestruktureerde geheel waarbinne daar 'n verteller, vertelde karakters en 'n verhaal in 'n gegewe tydruimtelike milieu voorkom. In die geval van Handelinge veronderstel die verteller natuurlik ook 'n sterk referensiële band tussen die inhoud van sy vertelling en die reële wêreld hierbuite, wat tot gevolg het dat die pragmatiese aard van hierdie teks geensins genegeer kan word nie. Reeds aan die begin van Handelinge gee hy byvoorbeeld al aanduidings aan sy leser dat die vertelling 'n verwysingspunt in die buitetekstuele realiteit het as hy in Handelinge 1:1-8 verwys na 'n historiese persoon (Jesus) wat op 'n bepaalde tydstip gesterf het, maar toe opgestaan het uit die dood en daarna die Heilige Gees aan sy volgelinge geskenk het om hulle toe te rus om sy getuies te wees. Hierdie vertelde gebeure vereis nou 'n sekere reaksie van die leser (soos wat die tekstuele aanduidings dit duidelik maak vgl die volgende afd), wat nie soseer die geval sou wees indien Handelinge geen aanspraak op enige buitetekstueie verwysing sou maak nie. 
(Die pragmatiese aard van Handelinge is egter nie bepalend vir die genre daarvan nie, maar hou eerder verband met die perspektief en oogmerk van die verteller. ${ }^{10}$

\section{Die plek van die Jerusalemgemeente binne die narratiewe raamwerk van Handelinge}

\subsection{Die narratiewe struktuur van Handelinge}

Omdat enige narratief "..einen Zeitpunkt, ein Verfahren (Erzählen), einen Sprecher (Erzähler), Zuhörer und eine mit diesem Verfahren verbundene Sache (Geschichte als Ereignis und Vorgang)" 11 ) bevat, moet tydens die interpretasieproses kennis geneem word van die verskillende verhoudings waarin hierdie aspekte tot mekaar staan. Sou daar nou na die verskillende verwysings na die Jerusalemgemeente in Handelinge gekyk word, dan blyk dit dat hierdie stof vanuit 'n bepaalde perspektief ("point of view") vertel word wat getipeer kan word as 'n derdepersoon-vertelling (die sg "auktoriale Erzählung"12), waarvolgens die outeur-verteller nie fisies deel van die vertelde wêreld is nie. (In die tweede helfte van Handelinge kom vier gedeeltes voor [die sg. "ons"-berigte] waar die outeur wel deel van die vertelde wêreld is.) Dit is belangrik om met hierdie vertellersperspektief rekening te hou. ${ }^{13)}$ Die outeur-verteller se fisiese afwesigheid by die gebeure maak dit vir hom baie makliker om oor die gebeure berig te lewer as wat die geval sou wees met'n eerstepersoonverteller wat nie van sy liggaamlikheid kan loskom sonder om aan die betroubaarheid van sy vertelling in te boet nie. Die eksteme vertellersperspektief wat Lukas handhaaf, skep in 'n groter mate die indruk van objektiwiteit en neutraliteit ten opsigte van die hantering van die tekstuele gegewens by die lesers as wat dit die geval is by eerstepersoonvertellers wat vanweë hul eksistensiële betrokkenheid by die verhaal meer bevooroordeeld in hul aanbieding van die feite voorkom. ${ }^{14}$ Enige verdere subjektiewe elemente wat nou in die vertelling aanwesig mag wees, word dus goed verbloem deurdat die verteller agter die vertelde karakters verdwyn. Gevolglik word die indruk geskep dat Handelinge 'n klinies-objektiewe verslag van die vertelde gebeure daarstel. Dié indruk van objektiwiteit word nog verder versterk deur die feit dat die verteller min na die innerlike gevoelens en emosies van die karakters verwys; die klem val merendeels op hul aksies en fisiese omstandighede. Deur middel van die vertellerstegniek word die (ideologiese) oogmerke van die outeur via sy mondstuk, die verteller, baie meer subtiel oorgedra om die beoogde leser tot instemming hiermee te probeer bring. Die verteller moet natuurlik nie met die implisiete outeur verwar word nie, soos wat Chatman tereg opmerk. ${ }^{15)}$ Die taak 
van die implisiete outeur agter die verteller is om die leser te onderrig aangaande die wyse waarop die teks gelees moet word. Alle gegewens binne die teks, soos die wyse waarop die stof gerangskik word, die posisie en rol van die verteller, kommentaar op die gebeure, ensovoorts, speel in hierdie verband 'n belangrike rol.

Aan die hand van 'n bepaalde tema, naamlik dat die Heilige Gees die werk van die opgestane Jesus voortsit (vgl verderaan), orden die verteller sy feite nou binne 'n bepaalde gestruktureerde patroon wat al die losstaande gebeure tot 'n geordende geheel saambind (die "plot" van die vertelling). ${ }^{16)}$ In die ontwikkeling van die plot maak Lukas gebruik van bepaalde narratiewe tegnieke om progressie in sy vertelling te verkry wat die leser van een segment in die verhaal na die ander moet voortlei. Grammatikale konstruksies, soos temporele koppelwoorde en partisipia, vervul eerstens sodanige funksie. Verder wissel hy ook verskeie narratiewe vorme met mekaar af soos toneelsketsing (bv Hand. 1:1-2:13; 6:1-7), wat die heel basiese narratiewe vorm is, ${ }^{17}$ vertellerskommentaar (bv Hand. 4:13;6:5), wat egter deur Hendricks ${ }^{18)}$ as "meta-narration" geklassifiseer word omdat dit volgens hom 'n afwyking van die suiwer narratiewe vorm van die verhaal vergestalt, en opsommings (bv Hand. 4:32-6). Toneelsketsing, wat deur Stanzel ${ }^{19)}$ omskryf word as "...a certain amount of dialogue accompanied by introductionary verbs, authorial 'stage directions', and at least some report of the action, even if extremely condensed" word dikwels deur Lukas in sy weergawe van die verhaal van die vroeë kerk aangewend. Volgens Prince ${ }^{20}$ maak vertellers gewoonlik van opsommings gebruik indien hulle iets wil beskryf wat noodsaaklik vir die verstaan van die verhaal is, terwyl toneelsketsing weer aangewend word om die aksies en gedagtes van die vertelde karakters in groter detail te beskryf. Hierdie toneelsketsing gee onder andere ook aanleiding tot groter lesersbetrokkenheid deurdat dit vir die leser voel asof hy die gebeure in actu beleef omdat heelwat inligting in verband met die vertelde karakters en die toneel waarteen die gebeure afspeel, verstrek word.

Kenmerkend van narratiewe gee Lukas reeds aan die begin van Handelinge, as inleiding tot die plot, sekere voorlopige aanduidings en inligting rakende die lees van sy geskiedvertelling, soos die wyse waarop die verteller in die verhaal aanwesig is, die tema van die skrywe, die hooffigure, die leser daarvan, ens. ${ }^{21)}$ Lukas verbind die Proömium van Handelinge baie prominent aan die Lukasevangelie deur sy vermelding van die eksplisiete leser van albei boeke, naamlik Teofilus. Teofilus as historiese leser (met ander woorde as leser buite die teks) bestaan egter nie meer nie, maar via die geimpliseerde leser binne die teks (wat natuurlik eksplisiet as Teofilus geïdentifiseer word) kry ons (indirek) 'n bepaalde indruk van die reele leser. "The implied reader becomes the route by 
which the author reaches for the heart of the real reader. The implied reader represents the response the author is aiming at or assuming on the part of his audience". ${ }^{22)}$ Ons leer die implisiete leser op sy beurt weer ken uit al die tekstuele aanwysings aangesien die teks in sy geheel 'n bepaalde beeld van hom daarstel.

Die verteller maak veral van vertellerskommentaar (as deel van die "besprochene Welt") gebruik om die geïmpliseerde leser tot instemming met sy vertelling te probeer bring. In hierdie verband word die verbaasde reaksie van die skare en veral dié van die eerste gelowiges op die werke van die apostels baie positief beoordeel (aangesien hy 'n korresponderende tipe reaksie van sy leser verlang), terwyl alle ander beskouinge (soos dié van die Joodse godsdienstige leiers en dié van 'n deel van die skare wat op Pinksterdag die apostels van dronkenskap beskuldig) totaal afgewys word. Die reële leser moet dus daartoe beweeg word om sonder voorbehoud met die norme en waardes van die verteller te identifiseer.

Die protagonis van die Lukas evangelie, naamlik Christus, tree in die eerste agt verse van Handelinge 1 as hooffiguur op en sy optrede en woorde verteenwoordig ook hier die oorheersende ideologiese "point of view" van die vertelling. Uiteraard bestaan daar uiteenlopende opvattings oor wat met die term "ideologie" bedoel word. ${ }^{23)}$ Met ideologiese "point of view" word hier egter aangesluit by Uspensky se definiëring van genoemde begrip as 'n "...system of ideas that shape the whole work.." wat deel kan wees van die "...author himself; or it may be the normative system of the narrator, as distinct from that of the author ... or it may belong to one of the characters". ${ }^{24)}$ Die ideologiese gesigspunt van Jesus wat in Handelinge vergestalt word in die aktiwiteit van die Heilige Gees deur wie die verhoogde Christus sy werk voortsit, verteenwoordig ook die gesigspunt van die outeur-verteller (én die implisiete outeur). Aan die hand van dié oorheersende "gesigspunt" word alle botsende beskouinge van teenstanders geëvalueer, asook die optrede van alle karakters wat die verteller deur die loop van die verhaal vermeld. Hierdie opvattinge wat Handelinge ten grondslag lê en wat vergestalt word in die oppervlaktestrukture (soos frases, vertellerskommentaar, psigologiese evaluasies, ens ${ }^{25)}$ word, soos reeds vermeld, vertel vanuit 'n posisie buite die gebeure. Die outeurverteller se fisiese afwesigheid beteken egter nie dat hy objektief en apaties tot die gebeure staan nie; trouens, sy ideologies-psigologiese betrokkenheid by die verhaal getuig juis van die teendeel.

Die Heilige Gees tree as die geimpliseerde protagonis op in die verhaal van die vroeë kerk (dit wil sê, die eintlike hoofkarakter agter die eksplisiet vermelde hooffigure). Tog vervang die Gees nie vir Christus nie, maar figureer $\mathrm{Hy}$ eerder (soos hierbo gesê) as bemiddelende persoon 
deur wie die verhoogde Christus sy heil na die gemeente en na die nasies toe bring. Daar bestaan dus 'n intieme band tussen Christus en die Gees. Dit is die Heilige Gees wat die onkunde en blindheid van die mense ten opsigte van die werke van God, wat so kenmerkend was van die dissipels en die skares ten aanskoue van die optrede van Jesus in die Lukasevangelie, en weer in Handelinge 1:6 met hul vraag oor die oprigting van die koninkryk van God, uit die weg sal ruim. Antisiperend van dié werking van die Heilige Gees en as kursoriese samevatting van die doel van Handelinge, sê Jesus aan sy dissipels in Handelinge 1:8 dat hulle krag sal ontvang wanneer die Heilige Gees oor hulle kom om sy getuies in Jerusalem, Judea en Samaria te wees. ${ }^{26}$ Hierdie antisipasie van die latere gebeure, ook bekend as temporele prolepsis, ${ }^{27}$ ) word algaande in die verteltyd van die verhaal van die vroeë kerk gerealiseer wanneer dit uit die plot duidelik word dat die evangelie sy loop deur die wêreld geneem het en ook dat Christus nog steeds in die kerk werksaam is deur die bemiddeling van die Heilige Gees.

$\mathrm{Na}$ die hemelvaart van Christus tree 'n nuwe eksplisiet vermelde hoofkarakter (en verteenwoordiger van die ideologiese gesigspunt in die verhaal) na vore, naamlik Petrus. Nie alleen word sy naam eerste in die naamlys van die apostels vermeld nie, maar hy neem ook die leiding by die verkiesing van 'n nuwe apostel. Die ideologiese gesigspunt van die outeur-verteller (waarvolgens die Heilige Gees Christus se werk op aarde voortsit) stem so sterk ooreen met die gesigspunt van Petrus as eksplisiete protagonis, dat hy hom algaande deur middel van sy optredes en toesprake as 'n model van die aardse Jesus voorhou. Tog beteken dit nie dat Petrus as 'n blote verlengstuk van die persoon van Jesus geskets word nie, ${ }^{28)}$ maar eerder as die ideale draer van die Gees deur wie die verhoogde Christus met sy aktiwiteite voortgaan. Die doel met hierdie ooreenkomste tussen Petrus en Jesus (ten spyte van die verskille in die inhoud van hul prediking) is om die kragtige teenwoordigheid van die Heilige Gees in Petrus in die besonder voor te stel omdat dieselfde Gees wat in die aardse Jesus werksaam was, die apostels en die gelowiges nou met die verrese Christus tot 'n eenheid verbind. ${ }^{29)}$

\subsection{Die rol van die Jerusalemgemeente binne die opsommings}

\subsubsection{Die funksie van Jerusalem}

Volgens die verteller ontstaan daar in reaksie op die prediking van Petrus in Jerusalem 'n eskatologiese gemeenskap as sigbare bewys van die vervulling van die belofte in Handelinge 1:8. Die ganse bestaan van dié Geesbeheerde gemeente binne bovermelde lokaliteit word volgens die 
opsommings gekenmerk deur lewenskragtigheid soos wat dit onder andere vergestalt word in die prysgawe van hulle besittings, hulle godsdienstige byeenkomste, ensovoorts. Tesame met hierdie innerlike vitaliteit vind daar ook 'n grootskaalse numeriese groei van die gemeente binne Jerusalem plaas sodat dit duidelik uit die vertelling blyk dat Christus se beloftes nie alleen net op kwalitatiewe wyse binne die nuwe gemeenskap in vervulling gegaan het nie, maar ook op kwantitatiewe wyse.

Jerusalem neem 'n belangrike plek binne hierdie beskrywing van die eerste gemeente in as die tyd-ruimtelike en topografiese lokaliteit waarbinne die verhaal aangaande hulle afspeel. Die uitstorting van die Heilige Gees in Jerusalem op Pinksterdag dien as 'n belangrike historieslokaliseerbare datum vir die ontstaanstyd van die gemeente, en as 'n konkrete aanduider van die vervulling van Christus se belofte in Handelinge 1:8. Jerusalem moet egter nie bloot gesien word as die neutrale vertrekpunt (die sg. "zero-punt") waarteen die verhaal van die vroeë kerk gelees behoort te word nie. Die hele geskiedenis van hierdie stad as die vernaamste heilshistoriese sentrum van God se handelinge met sy volk en die feit dat Jesus se aardse optrede hier geëindig het en die kerk sy oorsprong hier het, ${ }^{30)}$ beïnvloed immers die verteller se beskrywing van die gebeure wat hier afspeel (soos wat dit onder andere uit die tekstuele aanduidings in Handelinge 1 blyk). In dié verband lyk dit dan korrek om te sê dat Jerusalem as fisiese lokaliteit ook bepaalde geestelike waardes versimboliseer. Hierdie lokaliteit dien sodoende nie alleen as 'n belangrike ondersteuningselement tot die tema nie, maar terselfdertyd ook as 'n onontbeerlike faktor in die daarstelling van 'n bepaalde stemming of atmosfeer binne die verhaal. Dit sou dus foutief wees om die tyd-ruimtelike milieu waarbinne die eerste gemeente figureer slegs as die agtergrond of "setting" vir die gebeure rondom hulle te beskou. ${ }^{31}$

\subsubsection{Die eie aard van die opsommings binne die narratiewe raam- werk van Handelinge}

Die opsommings figureer binne die plot van Handelinge as mikroverhale met 'n eie storielyn en tyd, omdat hulle geen direkte temporele binding met die omringende stof het nie en ook vanweë die feit dat hulle afwyk van die deurlopende narratiewe patroon. (Dié versteuring van die kronologiese voortgang van die vertelling dra onder andere by tot die skepping van ruimtelikheid binne die verteltekste. ${ }^{32}$ ) Hierdie verbreking van die progressie word veral veroorsaak deur die feit dat dieselfde soort inligting in die afsonderlike opsommings verskaf word (vgl afd 2.2.3) wat die leser se aandag telkens op 'n retrospektiewe wyse teruglei na die vorige gedeelte. As literêre tegniek is dié metode baie effektief aangesien dit die leser be- 
trokke hou by die verhaal, omdat hy as't ware gedwing word om elke nuwe opsomming te vergelyk met die inligting wat hy reeds tot sy beskikking het. Sodoende verseker die verteller deur middel van hierdie onderbreking van die vertelde tyd van die verhaal dat die leser al die gegewens oor die vroeë kerk deeglik onder oë kry; iets wat waarskynlik nie sou gebeur het indien hy al die opsommings in een berig sou saamgevoeg het nie. Tog is dit opvallend dat die outeur in elke nuwe opsomming telkens nog verdere inligting in verband met die gemeente beskikbaar stel wat aansluit by en uitbrei op die vorige gedeelte. Daar is dus 'n mate van progressie tussen die opsommings te bespeur. Deur middel van hierdie werkswyse plaas die verteller dus baie klem op die opsommings, maar ook deur die opvallende afwesigheid van enige inhoudelike verbinding van dié gedeeltes aan die episodiese tonele wat hulle omring.

'n Verdere kenmerk van al drie opsommings is dat hulle die verskillende aspekte van die gemeente se religieus-eksistensiële bestaan aan die hand van iteratiewe vertelvorme weergee (dit wil sê, waar een sinsnede in die verteltyd 'n hele aantal gebeure saamvat). ${ }^{33)}$ So maak Handelinge 2:43 byvoorbeeld melding van die "baie" wonders van die apostels, terwyl 2:46 weer verwys na die "daaglikse" byeenkomste in die tempel, die breek van brood "van huis tot huis" ensovoorts. Die doel met dié vertelwyse is om eerstens die analogiese verband tussen hierdie herhalende gebeure aan te dui en om ook aan die hand van die beklemtoning van die reëlmaat van die gebeure 'n oorsigtelike beeld van die gemeentelike bestaan daar te stel. Deur middel van hierdie iteratiewe verteltegniek word die indruk dus geskep dat die afsonderlike gebeurtenisse nie lineêr op mekaar volg nie, maar dat hulle eerder tegelykertyd en voortdurend plaasvind. (Die tydskonsep binne sodanige vertellings is dus organies van aard.) Terwyl die omringende episodiese vertellings dan 'n bepaalde temporele opeenvolging van gebeure veronderstel, word die reëlmatigheid van die vertelde gebeure in die opsommings benadruk waardeur die verteller dit wil duidelik maak dat die gedrag van die eerste gemeente nie net uit 'n aantal losstaande (en verbygaande) episodes bestaan het nie.

Dieverteller wissel bepaalde "vertel-" en "wystegnieke" in die opsommings en die omringende narratiewe materiaal effektief met mekaar af. ${ }^{34)}$ Die opsommings (waar vertel word) is sonder twyfel duidelik geinterpreteerde weergawes van bepaalde gebeure, wat nie juis veel vryheid aan die leser oorlaat om dit anders te verstaan nie. Aan die ander kant laat die episodiese vertellings met hul baie dialoog weer heelwat ruimte aan die leser om die gebeure op sy eie manier te interpreteer omdat die verteller slegs aan hom wys hoe sekere karakters optree. Deur afwisseling van die verteltegnieke (deur nou in die opsommings te vertel en netnou in die episodiese vertellings te wys) skep die verteller op die ou end 'n bepaalde 
beeld van die vroeë kerk by die leser (met die klem egter steeds op die opsommings). Alhoewel die verteller dan groter vryheid van interpretasie aan die leser binne die episodiese vertellings verleen, korrigeer en rig hy dit tog binne die opsommings op 'n bepaalde manier. Die beeld wat binne die opsommings van die eerste gelowiges geskep word, dien met ander woorde as die norm vir die verstaan van die omringende vertellings, en nie andersom nie.

\subsubsection{Deurlopende temas binne die opsommings}

Die opsommings vertoon 'n groot aantal inhoudelike ooreenkomste met mekaar

(1) Getrou aan die opbou van die verhaal figureer Petrus en die apostels eerstens baie prominent binne hierdie gedeeltes, soos byvoorbeeld in Handelinge 2:42 waar vermeld word dat die gelowiges volhard in die leringe van die apostels, terwyl vers 43 verwys na die "baie wonders en tekens" van die apostels. In die tweede opsomming (Hand. 4:32-5) word melding gemaak van die kragtige getuienis van die apostels aangaande Jesus se opstanding uit die dood, en in verse 34 en 35 berig Lukas dat die gemeentelede hul besittings aan die voete van die apostels kom neerlê het, wat dit op hulle beurt weer uitgedeel het aan die behoeftiges. In die derde opsomming (5:12-16) is daar in vers 12 nog 'n verwysing na die wonders en tekens wat deur die apostels verrig is, asook ' $n$ vermelding van die genesingswonders van Petrus (vers 5).

Verdere deurlopende motiewe is:

(2) Die vermelding van die groot en gereelde getalstoename van die eerste gemeente. Hoofstuk 2:41 b, as oorgang tot die eerste opsomming, vermeld die toevoeging tot die gelowiges van sowat drieduisend mense op Pinksterdag. Handelinge 2:47b noem dat God elke dag nuwe lede bygevoeg het tot die eerste kerk. In hoofstuk 5:14 vertel Lukas dat baie mense tot die geledere van die Christene toegevoeg is.

(3) Twee verwysings na die volharding van die gelowiges kom in Handelinge 2:42 en 46 voor, en

(4) Die reaksie van die eerste Christene op die werke van God (as deel van die vertellerskommentaar) word vermeld in Handelinge 2:43 ("almal is met diepe ontsag vervul"), en weer in 5:5 en 11. Hierdie religieuse vrees wat posvat in teenwoordigheid van die werke van God weerspieël natuurlik die ideale reaksie waartoe die skrywer sy beoogde leser wil probeer beweeg.

(5) 'n Vyfde motief, wat sekerlik die opvallendste in die opsommings 
figureer, is die geestelik-materiële eenheid van die gelowiges wat uitdrukking vind in hulle religieuse handelinge en in hul gemeenskaplike besit. In dié verband gebruik die outeur terme soos koinonia (2:42); epi to auto (2:44); kardia kai psuge mia (4:32); homothumadon (2:46), en veral dan die uitdrukking hapanta koina (2:44 en 4:32).

Wat die strukturele opbou van die opsommings betref, sien dit breedweg soos volg daar uit:

(a) 'n Inleidende gedeelte waar die tema van die hieropvolgende mikroverhaal aan die orde gestel word.

(b) Die hoofgedeelte waarbinne daar uitgebrei word op die tema waarna die inleiding verwys.

(c) Afsluiting van die verhaal waar een of ander suksesvolle afloop van dit wat in (a) aangekondig, en in (b) verder uitgewerk is, uitgebeeld word.

Skematiese voorstelling van die struktuur van die opsommings

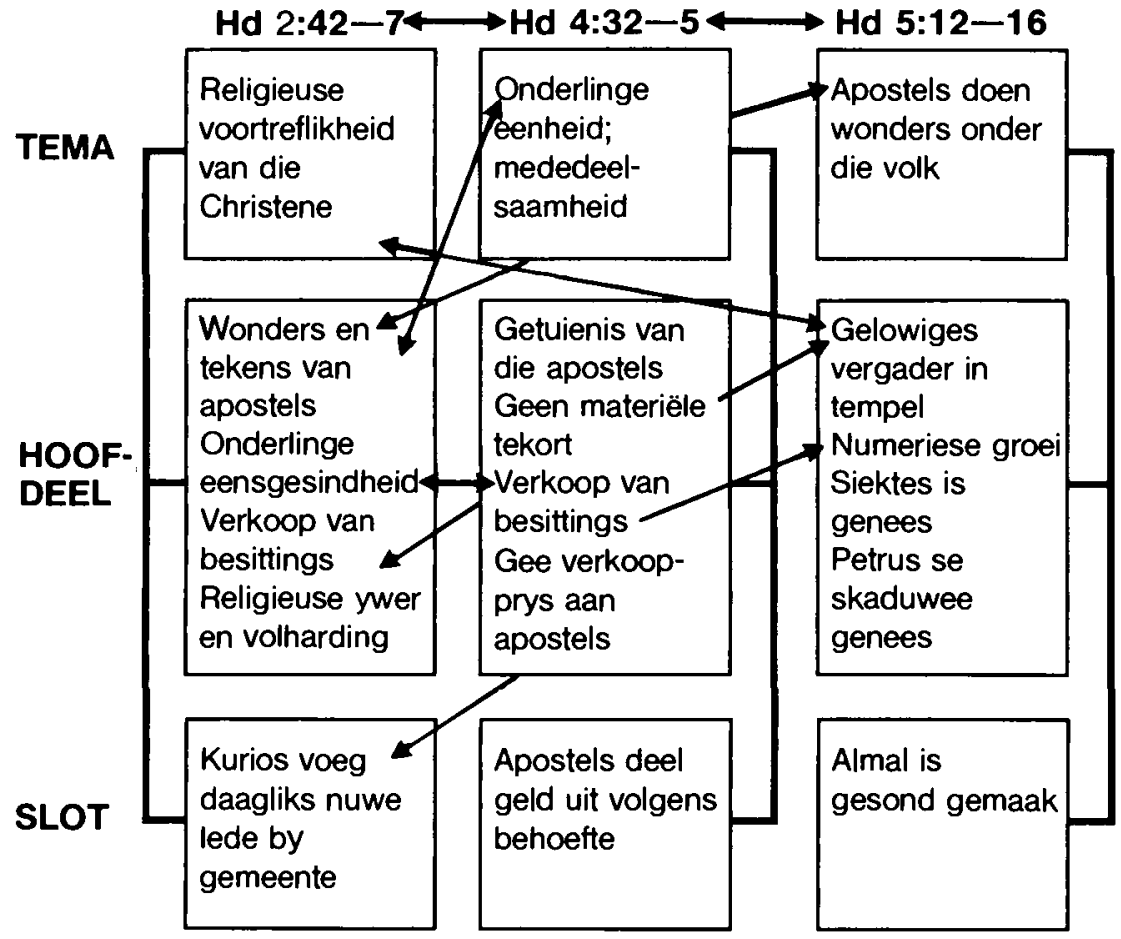


Hierdie deurlopende motiewe in die opsommings benadruk die ideologiese eenheid van die gelowiges as resultaat van die Heilige Gees se werking. Teenoor die ontaarde mense buite die gemeentegrense (waarop in die omringende vertellings gewys word - bv Hand. 2:40) fokus die opsommings op die verlossing en vryheid wat die gemeente nou ervaar; teenoor die onsekerheid van die godsdienstige leiers van die Jode (Hand. 4:5-21) heers daar harmonie en standvastigheid binne die gemeente. Alhoewel die gelowiges dan binne dieselfde oorkoepelende topografiese ruimte (te wete Jerusalem) as die buitestaanders bestaan, grens hul geloof in die opgestane Christus hulle radikaal van eersgenoemde af. Diegene in Jerusalem, maar buite die gemeente is sodoende die verlorenes (Hand. 4:11-12;5:14) aan wie die evangelie verkondig word sodat hierdie stad dan die eerste topos word waar Christus se belofte in Handelinge 1:8 in vervulling gaan!

Volgens baie navorsers is hierdie beeld wat Lukas in die opsommings van die Jerusalemgemeente skets, histories onbetroubaar aangesien dit 'n uiters tendensieuse en idealistiese voorstelling van die "eintlike situasie" wou weergee. ${ }^{35)}$ Vroeër in die artikel is egter opgemerk dat betroubaarheid ook 'n literêre begrip is wat verband hou met 'n outeur se getrouheid aan die norme wat hy vir sy werk daargestel het. Sou dit in gedagte gehou word, en die opsommings vanuit hierdie perspektief beskou word, blyk dit dat die verteller van Handelinge nie van sy neergelegde norme afgewyk het nie. Die tema van die boek, te wete die Heilige Gees wat as implisiete protagonis die werk van die opgestane Christus in die wêreld (aanvanklik) via Petrus (en in 'n mindere mate die ander apostels) voortsit, is ongetwyfeld soos 'n goue draad deur die opsommings vervleg. Nie alleen word dit duidelik geillustreer in die positiewe respons op Petrus se prediking op Pinksterdag nie, maar ook uit die ontsag wat die apostels se algemene optrede by die gemeente ontlok, die eensgesindheid onder laasgenoemdes, die prysgawe van hul besittings, ensovoorts.

Uiteraard moet toegegee word dat Lukas se aanbieding van die stof in die opsommings bepaalde tendense vertoon. Maar dan moet pasgenoemde opmerking onmiddellik gekwalifiseer word deur te sê dat enige vertelling in elk geval vanuit 'n bepaalde gesigspunt ("point of view") aangebied word.

Dit dien immers geen doel om 'n aantal (historiese) feite bloot in kronologiese volgorde op mekaar te stapel nie; hulle moet ook vertel word. Dit wil sê, die onderlinge samehang tussen die vertelde gebeure moet blootgelê word en die vertelling moet onder andere ook aan die "..condition of narrative smoothness" voldoen. ${ }^{36)}$ Die aanwesigheid van bepaalde tendense dui dus nie per se op "historiese onbetroubaarheid" soos wat vele navorsers blykbaar wil aanvaar nie. 
Die verteller van Handelinge, wat homself (as simpatieke verteller) onomwonde met die standpunt van die eksplisiete en implisiete protagoniste identifiseer, het dit nie ten doel om 'n omvattende omskrywing van al die fasette van die lewe van die Jerusalemgemeente weer te gee nie. Indien hy dit so gedoen het, sou ons eerder rede gehad het om hom as 'n onbetroubare verteller uit te wys. Getrou aan sy eie norme beskou hy egter die Jerusalemgemeente net as helpers wat die eksplisiete protagonis help om die werk van die Heilige Gees in Jerusalem te laat realiseer. Terselfdertyd is hulle as begunstigdes ook die objekte van laasgenoemde se werk. Al wat die leser aangaande die Jerusalemgemeente behoort te weet, is dat hulle positief op die apostoliese prediking gereageer het en dat die werking van die Heilige Gees hulle hele bestaan ingrypend verander het.

\section{Samevattende opmerkings}

Wat die funksie van die Jerusalemgemeente binne die opsommings betref, blyk dit uit die voorafgaande bespreking dat hierdie gedeeltes in diens van die tema van die hele vertelling staan; daarom moet dit ook in hierdie lig beoordeel word. Die Jerusalemgemeente dien met ander woorde as die konkrete bewys van die vervulling van die eerste gedeelte van Christus se belofte in Handelinge 1:8. Terselfdertyd dien die verwysings na hulle fisiese en godsdienstige samehorigheid binne hierdie bepaalde geografiese lokaliteit ook as 'n sigbare teken van die voortgesette teenwoordigheid van die opgestane Christus in die midde van sy kerk. Alle gegewens wat Lukas in die opsommings, en ook elders in Handelinge, in verband met hul aktiwiteite verskaf, is uiteraard geselekteer om by hierdie oogmerke in te pas. Hy het dit geensins ten doel om 'n omslagtige karakteruitbeelding of detailbeskrywing van die optrede van die Jerusalemgemeente daar te stel nie; hulle vervul slegs 'n funksionele rol ter ondersteuning van die tema van die verhaal. Daar kan dus binne die raamwerk van die vertelling geen sprake van enige multi-dimensionaliteit in die Lukaanse uitbeelding van hierdie mense wees nie; as sekondêre karakters of helpers word hulle bloot staties voorgehou.

Die Jerusalemgemeente dien uiteraard ook as 'n identifikasiemedium vir die lesers. Lukas beoordeel hulle reaksie op die optrede van die protagonis van die verhaal in uiters positiewe terme. Deur middel van ideologiese vertellerskommentaar kontrasteer hy telkens die twee moontlike reaksies van mense op die optredes van die apostels, te wete, dié van die godsdienstige teenstanders (Handelinge 2:12; 4:21), wat natuurlik deur die eksplisiete protagonis beoordeel en afgewys word (vgl bv Handelinge 3:12-26), en dié van die gelowiges (vgl al die opsom- 
mings), wat as die enigste aanvaarbare en korrekte reaksie op die werke van God voorgehou word. Die verteller maak egter nie net van ideologiese kommentaar op die gebeure gebruik nie, maar ook van persoonlike kommentaar ".to dictate the reader's perception of, and response to, the characters.." ${ }^{37}$ ) Hy doen dit egter vanuit 'n eksterne perspektief aangesien hy nie in die opsommings na die interne gedagtes en belewenisse van die Jerusalemgemeente verwys nie, maar eerder op hulle uiterlik waarneembare goeie hoedanighede konsentreer. Hulle is eensgesind, vol blydskap, hulle prys God, hulle kom getrou in die tempel bymekaar, deel hulle besittings met mekaar, ensovoorts.

Aan die hand van hierdie vertellerskommentaar word die leser gelei om hom met die Jerusalemgemeente te identifiseer. Identifikasie beteken egter nie 'n oppervlakkige nabootsing of eksemplariese herhaling van laasgenoemde se gedrag nie, maar eerder 'n vereenselwiging met die norme onderliggend aan hul gedrag. Die leser van Handelinge word met ander woorde na analogie van die optrede van die eerste gelowiges geroep om eweneens 'n positiewe respons op die apostoliese verkondiging te lewer as die enigste legitieme reaksie op Christus se voortgesette werk deur die Heilige Gees.

Indien die tekstuele aanwysings wat die verteller self vir die interpretasie en verstaan van Handelinge aanbied, wel gevolg word, behoort dit nie alleen te lei tot ' $n$ nuwe waardering van Lukas se vermoëns as verteller nie, maar ook tot groter begrip vir sy hantering van die historiese gegewens binne die narratiewe raamwerk van sy vertelling.

\section{NOTAS}

1. F.C. Baur, Geschichte der christlichen Kirche. 1. Teil, Leipzig.[1863] 1969, 42.

2. Aldus W. Gasque, A history of the criticism of the Acts of the Apostles, Tübingen 1975, 136-163.

3. Vgl. bv. F.W. Horn, Glaube und Handeln in der Theologie des Lukas, Göttingen 1983, 43; N. Walter, "Apostelgeschichte 6,1 und die Anfänge der Urgemeinde in Jerusalem" NTS vol. 29 (1983), 370-393, en R Pesch, Die Apostelgteschichte. 1 Teil. Apg 1-12, Neukirchen 1986, 188-194.

4. W.C. Booth,The rhetoric of fiction, Chicago $21983,158-159$.

5. Vgl. onder andere J. Culler, "Prolegomena to a theory of reading", in SR Suleiman \& I Crosman (eds), The reader in the text. Essays on audience and interpretation. Princeton 1980,52, en U Eco, The role of the reader. Explorations in the semiotics of texts, Bloomington 1980, 6.

6. W.S. Vorster, "Op weg na 'n post-kritiese Nuwe-Testamentiese wetenskap", HTS vol 43 (1987), 383.

7. S. Fish, "Interpreting the Variorum", in JP Tompkins (ed), Reader response criticism: From formalism to post-structuralism, Baltimore 1980, 177.

8. R. Johl, Kritiek in krisis: Vryheid vir die teks, Durban 1986, 159-160. 
9. R. Scholes \& R. Kellogg, The nature of narrative, London 1966, 240. Vgl ook I. Gräbe, "Narratologiese ondersoek en eksegese van die boodskap van die evangelies",HTS vol 42 (1986), 151-169.

10. W.A. Kort, "Narrative and Theology", Journal of Literature \& Theology vol 1. (1987), 27-39, wys daarop dat dit foutief is om 'n onderskeid tussen historiese en fiktiewe narratiewe te maak. "The narrative world is unified, and the historical and fictional in narrative are matters of emphasis and not two, separate kinds of discourse" (bl. 29).

11. K. Kanzog, Erzählstrategie, Heidelberg 1976, 9.

12. F. Stanzel, Die typische Erzäh/situation im Roman, Stuttgart 1955, 38.

13. Die derdepersoonverteller van Handelinge vertel sy storie vanuit 'n alomteenwoordige gesigspunt aldus W.S. Vorster, "The New Testament and narratology", JLS vol 2/3 (1986), 56-7. Dit wil sê, hy het onder andere insig in die gedagtes, gevoelens en emosies van die verteldekarakters wat ' $n$ eerstepersoonverteller nie het nie. Om egter uit die alomteenwoordige perspektief van sekere Bybelse vertellers afleidings rakende die Bybelse realiteitsmodel en sy gesagsaansprake te maak, soos wat M. Steinberg. The poetics of Biblical narrative. Ideological literature and the drama of reading, Bloomington, 1985, probeer doen, is nie verantwoordbaar nie. Uitsprake van Steinberg, soos: "Models of narration ... link with models of reality, sacred and profane" (87-8); en: "The very choice to devise an omniscient narrator serves the purpose of staging and glorifying an omniscient God" (bl. 89) berus op tekseksterne aprioriese aannames wat geensins uit 'n analise van die "point of view" van die verteller van die tersake tekste geregverdig kan word nie.

14. F. Stanzel, $\mathcal{A}$ theory of narrative,London 1984, 150.

15. S. Chatman, Story and discourse: Narrative fiction and film, Ithaca 1978, 148, noem dat die implisiete outeur "...is not the narrator, but rather the principle that invented the narrator, along with everything else in the narrative ... Unlike the narrator, the implied author has no voice, no direct means of communicating. It instructs us silently...". Vgl in dieselfde verband ook J.D. Kingsbury, Matthew as story, Philadelphia 1986, 36-7.

16. Vgl.J.C.de Klerk, “The New Testament as literature”, in J.C. de Klerk \& W. Schnell, $A$ new look at Jesus. Literary and sociological-historical interpretations of Mark and John, Pretoria 1987, 13-14; P. Ricoeur, Time and narrative, Chicago 1984, 65, en R.A. Culpepper, Anatomy of the fourth Gospel. A study in literary design, Philadelphia 1983,85 vir 'n meer breedvoerige omskrywing van die term "plot".

17. Booth, aw, 154 .

18. W.O. Hendricks, "The structural study of narration: Sample analyses", Poetics vol 3 (1972), 101.

19. Stanzel, aw, 1984, 143.

20. G. Prince, Narratology: The form and function of narrative, Berlin 1982, 58.

21. F.J. Matera, "The plot of Matthew's Gospel", CBQ vol 49 (1987), 233-253, wys daarop dat "..plot concerns time inasmuch it must have a beginning, middle, and end" (bl 235).

22. B. Lategan, "Reference: reception, redescription, and reality", in B.C. Lategan \& W.S. Vorster, Text and reality. Aspects of reference in Biblical texts, Philadelphia 1985, 70.

23. Volgens J. Senekal en E. Engelbrecht, "Terme" in J. Senekal (red), Teks-leser-konteks. Gedigte ontleed volgens eietydse metodes, Johannesburg 1986, 167, dui ideologie onder andere op (a) waardes wat in sisteme georganiseer is, en (b) potensiële semiotiese prosesse. Volgens K. McCormick en G.F. Waller, "Text, reader, ideology. The interactive nature of the reading situation", Poetics vol.16(1987), 193-208, 
is ideoiogie die "...beliefs, assumptions, habits, and practices of a particular society". Hierdie ideoiogie "..is inscribed within the words, the rule-systems, and the codes that constitute the text", cf veral 196-197.

24. B Uspensky, A poetics of consumption. The structure of the artistic text and typology of compositional form, Berkeley 1973, 8; asook A.G. van Aarde, "Narrative point of view": An ideological reading of Luke 12:35-48" 1-3. Referaat gelewer tydens NTWSA Kongres, April 1988. Vgl ook S. Chatman, "Characters and narrators. Filter, center, slant, andinterest-focus" PoT vol 7 (1986), 189-204, wat van mening is dat "point of view" nie maar net uitdrukking gee aan "..mere perception and cognition" nie, maar ook aan bepaalde ideologiese opvattings (bl 191).

25. Aldus A.G. van Aarde, "Die vertellersperspektief-analise 'n Literatuurteoretiese benadering in die eksegese van die evangelies", HTS vol 38 (1983), 62.

26. Vgl. ook I.H. Marshall, Luke - Historian and theologian, Exeter 1979, 157-158 en U. Wilckens, Die Missionsreden der Apostelgeschichte. Form- und traditionsgeschichtliche Untersuchungen, Neukirchen 1974, 58 wat die tema van Handelinge op soortgelyke wyse omsknyf.

27. G. Genette, Narrative discourse, Oxford 1980, 67.

28. H. Flender, St. Luke: Theologian of redemptive history, Philadelphia 1967, 139.

29. G. Muhlack, Die Parrallellen von Lukas-Evangelium und Apostelgeschichte, Frankfurt 1979, 138.

30. R. Zingg, Das Wachsen der Kirche; Beiträge zur Frage der lukanischen Redaktion und Theologie, Freiburg 1974, 144. Vergelyk ook E.S. Malbon, Narrative space and mythic meaning in Mark, San Francisco, 1986, 47-50, se bespreking van die rol van Jerusalem as deel van die geopolitiese ruimte in die Markusevangelie.

31. L.S.Venter,"Narratiewe ruimtes", Tydskrif vir Geesteswetenskappe vol 25 (1985), 19-29.

32. R. Smitten \& A. Daghistany, Spatial form in narrative, London 1981, 3.

33. Genette, aw, 116.

34. P. Lubbock, The craft of fiction, London, 1957, 62, het hierdie onderskeid tussen "showing-telling" in tekste veral bekend gemaak.

35. Vgl bv G. Gerhardsson, “Einige bemerkungen zu Apg 4,32", StTh vol 24 (1970), 147; L. Schottroff \& W. Stegemann, Jesus von Nazareth - Hoffnung der Armen, Stuttgart 1978, 150 en Walter, aw, 376.

36. A.R. Louch, "History as narrative”, H\&T vol 54 (1969), 57.

37. C.D. Malmgren, "Reading authorial narration. The example of the Mill on the Floss", PoT vol. 7 (1986), 485. 